\title{
Tasa-arvon ja yhdenvertaisuuden kysymykset uudelleen mietittyinä
}

Leena-Maija Rossi (2015). Muuttuva sukupuoli. Seksuaalisuuden, luokan ja värin politiikka.

Gaudeamus: Helsinki. 214 s. ISBN: 978-952-495-373-3

AIVAN HILJATTAIN OLEMME Saaneet kuulla ja lukea julkisuudessa esitettyjä puheenvuoroja, joiden mukaan turvapaikanhakijat muodostavat erityisen uhkan suomalaisille naisille ja sukupuolten tasaarvolle maassamme. Uusnationalististen ja oikeistopopulististen liikkeiden kannatuksen myötä niin Suomessa kuin muuallakin Euroopassa maahanmuuttoa vastustavat ja jopa rasistiset käsitykset ovat saaneet yhä enemmän jalansijaa ja siirtyneet valtapolitiikan areenoille ja julkiseen puheeseen.

Pohjoismaat, jotka ovat pitkään esiintyneet universaalin kansalaisuuden, tasa-arvon ja naisystävällisen hyvinvointivaltion tavoittelijoina, ovat yhtäkkiä muuttuneet "ulossulkevan nationalismin" ja "omille rajatun hyvinvoinnin" linjausten mallimaiksi - etunenässä Norja, Suomi ja Tanska (Keskinen, Näre \& Tuori 2015, 2-4). Näissä perinteisesti vahvan tasa-arvodiskurssin yhteiskunnissa inkluusion ja ulossulkemisen politiikat kiinnittyvät keskeisellä tavalla myös sukupuolen ja seksuaalisuuden normittamiseen. Kuten Keskinen, Näre ja Tuori (emt., 3) kuvaavat osuvasti: "sen, joka haluaa tulla osaksi kuviteltua suomalaisuutta, tulee omaksua tietynlainen käsitys sukupuolten välisistä suhteista, tasa-arvosta ja seksuaalisesta vapaudesta".

Tätä taustaa vasten arvioituna Leena-Maija Rossin teos Muuttuva sukupuoli on erittäin tervetullut ja tarpeellinen perehdytys sukupuolen, seksuaalisuuden, rodun ja luokan tutkimuksen keskeisiin käsitteisiin ja niiden välisiin suhteisiin.

Rossi itse motivoi kirjan koostamista tarpeella syventää ja laajentaa ymmärrystä sukupuoleen liittyvistä eriarvoisuuksista. Rossin mukaan Suomessa tasa-arvo ymmärretään edelleen pääasiassa kahden sukupuolen, naisten ja miesten välisinä, valta- ja eriarvoisuussuhteina, ei sukupuolten sisäisinä eroina, puhumattakaan erojen yhteisvaikutuksesta ihmisten arvottamiseen ja arvostamiseen.

Vaikka sukupuolten välinen ja myös seksuaalinen tasa-arvo ovat maamme virallisessa politiikassa huomion kohteina, ovat ne edelleen yhteiskunnallisia kiistakysymyksiä. Lisäksi monikulttuurisuuteen opettelevassa yhteisössä sukupuolen, seksuaalisuuden, ihonvärin, etnisyyden ja luokan monimutkainen yhteen kietoutuminen tuottaa eriarvoisuutta, joka usein jää näkymättömiin. Rossi kysyykin kirjan viimeisessä luvussa mielestäni koko teoksen tärkeimmän kysymyksen: "miten avata tasa-arvon ymmärtämistä avarammaksi?"

NORMIKRIITTINEN LÄHESTYMISTAPA

Rossin kirja koostuu hänen muokkaamistaan ja suomeksi kääntämistään artikkeleista, joita on ai- 
kaisemmin julkaistu tieteellisissä lehdissä ja kokoomateoksissa. Tämä formaatti ei sinällään haittaa lukijaa, vaan kirja toimii kokonaisuutena melko hyvin. Kertaalleen julkaistut artikkelit työstettyinä kirjan luvuiksi ja keskenään keskustellen etenevät johdonmukaisesti ja avaavat monipuolisesti eriarvoisuuksien tutkimuksen käsitteistöä. Samalla ne tarjoavat esimerkkejä aineistoanalyysistä.

Kirjan lukuja yhdistävänä näkökulmana on sukupuolen tutkimuksen ja kriittisen seksuaalitutkimuksen (queer-tutkimus) piiristä lähtöisin oleva normikriittinen lähestymistapa. Huomion kiinnittäminen normiin tarjoaa mahdollisuuden keskustella eriarvoisuuteen liittyvistä kategorioista vähemmän pakottavina ja enemmän käyttäytymistä ohjaavina, säätelevinä asioina (kuin esimerkiksi käytettäessä järjestelmän käsitettä). Toisaalta normi ei ole sama asia kuin sääntö tai sopimus. Butlerilaisittain tarkastellen se on pikemmin normalisoitunutta tai tavanomaiseksi tullutta toimintaa, joka paitsi pakottaa ja rajaa myös mahdollistaa toisin tekemisen, uuden oppimisen ja vastarinnan. Normikriittisyys puolestaan tarkoittaa normalisoinnin purkamista, näkyväksi tekemistä ja irrottautumista "normaalin" vallasta.

Kirjassaan Rossi on ottanut tehtäväkseen kahden keskeisen ja näkymättömän normin, heterouden ja valkoisuuden, näkyväksi kirjoittamisen. Läpi teoksen hän samalla etsii välineitä toisenlaisen - antinormatiivisen sukupuolen ja seksuaalisuuden sekä antirasistisen - politiikan tekemiseen.
Kirja jakautuu käsitteellisesti ja temaattisesti seitsemään osaan (vaikka kirjan lukuja onkin kahdeksan). Viisi ensimmäistä lukua painottuvat sellaisten keskeisten teoreettisten käsitteiden, kuten heteronormatiivisuuden, performatiivisuuden, representaation, intersektionaalisuuden ja identiteetin problematisoivaan tarkasteluun. Kuudennessa ja seitsemännessä luvussa näiden käsitteiden analyyttistä voimaa koetellaan audiovisuaalisen aineiston, kahden televisiosarjan (Gilmoren tytöt ja Mogadishu Avenue) tutkimuksessa. Viimeisessä luvussa Rossi keskittyy pohtimaan tutkimuskirjallisuuden ja omien havaintojensa pohjalta ratkaisuja kysymykseen, miten analysoida ja purkaa normittavaa ja luonnollistavaa, eriarvoisuutta ja epäoikeudenmukaisuutta generoivaa, valkoisuutta.

\section{KÄSITTEIDEN PURKAMISTA}

Teoksen normikriittinen missio tarkentuu heti ensimmäisen luvun heteronormatiivisuuden käsitteen pohdinnassa. Heterouden näkyväksi tekeminen edellyttää myös heteronormatiivisuuden käsitteen purkamista ja problematisointia.

Rossin mukaan käsitteen käytön ongelmiin liittyy sen sulautuminen (normatiivisen) heteroseksuaalisuuden käsitteeseen, minkä takia heteroutta tarkastellaan yhtenäisenä ilmiönä. Silloin heterouden erilaiset ja epänormatiiviset muodot jäävät piiloon. Kuitenkin heterous, kuten homouskin, on monimuotoista eikä kaikki heterous ole normatiivista. Tästä esimerkkeinä Rossi nostaa heteroiden vapaaehtoisen lisääntymättömyyden, pariutumattomuuden ja seksittömyyden.

Rossin ajaman normikriittisen analyysin tehtävänä on paitsi murentaa hetero/homo -vastakkainasettelua ja kyseenalaistaa heterouteen liittyviä etuoikeuksia myös purkaa heterouden sisäisiä hierarkioita. Tällä tavoin heterouden näkeminen ei pelkästään ei-heteroiden taistelun kohteena vaan myös heteroiden keskinäisen kamppailun kenttänä merkityksellistää heteroutta uudestaan (heterouden outouttaminen). Tällöin sen normatiivista valtaa on helpompi vastustaa.

Niin heterouden kuin valkoisuudenkin monimuotoisuuden ja sisäisten hierarkioiden purkamisessa tärkeä väline on intersektionaalisuuden käsite, jonka Rossi on suomentanut erojen leikkaamiseksi, risteämiseksi ja yhteisvaikutukseksi. Analysoitaessa heteroutta (seksuaalisuutta) ja valkoisuutta (ihonväriä) esimerkiksi sukupuolen, luokan, etnisyyden ja iän kanssa yhteen kietoutuneina, toisiinsa vaikuttavina sekä kulttuurisesti ja historiallisesti rakentuvina kategorioina on mahdollista tuoda esiin niiden sisältämiä eroja ja purkaa jähmeitä vastakkainasetteluja.

Erilaisia tekijöitä valottamalla voidaan muuttaa totunnaisia tapoja ymmärtää heterous ja valkoisuus sekä kyseenalaistaa näiden "luonnollisuus". Esimerkin "luonnollista” ja norminmukaista valkoisuutta rikkovasta lähestymistavasta Rossi antaa analyysissään suomalaisesta Mogadishu Avenue televisiosarjasta. Se nostaa kerronnassaan esiin valkoisuuden sisäisiä eroja sekä luokan ja sukupuolen toisiinsa kietoutumista tavalla, jossa katsojalle tarjoutuu 
mahdollisuus tarkastella kriittisesti valkoisuutta normina ja pääomana (luku 7). Rossin mukaan sarjassa puretaan stereotyyppistä ajattelua huumorin keinoin: "vitivalkoinen" ja heteroseksuaalinen suomalaisuus esitetään yleisölle välillä oudoksi sävytettynä, kun taas "muun värinen" suomalaisuus (sarjan maahanmuuttajataustaisten Muhammedin, Jussufin ja Abdin hahmossa) saa yllättäen hyvinkin tuttuja ja tunnistettavia piirteitä.

\section{KIELI POLIITTISINA TEKOINA}

Läpi Muuttuvan sukupuolen Rossin kirjoittamista leimaa kaksinapaiselle vastakkainasettelulle rakentuneen merkityksenmuodostuksen haastaminen. Rossin tasa-arvoohjelmassa keskeistä on kamppailu merkityksistä: vakiintuneiden merkitysten saattaminen liikkeeseen ja asioiden merkityksellistäminen uudestaan. Nämä ovat poliittisia tekoja, koska merkityksiä ja representaatiota rakentamalla tuotetaan samalla todellisuutta; normitetaan sukupuolta, seksuaalisuutta, luokkaa ja ihonväriä, arvotetaan erilaisia ihmisiä, käytäntöjä ja esineitä.

Rossi pohtii pitkään erilaisten representaatioiden samoin kuin kielellisten ja visuaalisten esitysten ja toistotekojen poliittista ulottuvuutta (luvut 3 ja 4 ). Hänen vastattavakseen asettuvat yhä uudestaan kysymykset siitä, miten vastustaa ja muokata stereotyyppisiä ja hierarkkisia eroja rakentavia representaatioita, kuinka merkityksellistää käytettyjä kategorioita uudestaan ilman, että asioita luonnollistetaan, mytologisoidaan tai normalisoidaan.

Tässä kohtaa tärkeäksi tutkimustehtäväksi tulee yhtä lailla paitsi uudenlaisten ja monipuolisten representaatioiden - toisin toistamisen ja esittämisen tapojen - löytäminen myös sen kriittinen analysointi, miten normeja asettavat esitykset ja toistot muotoutuvat. Millaisin merkein ja merkkiyhdistelmin heteroseksuaalista sukupuolisuutta ja valkoisuutta jatkuvasti tehdään, toistetaan ja esitetään.

Kaiken kaikkiaan Muuttuva sukupuoli on suositeltavaa lukemista kaikille niille, jotka ovat kiinnostuneita sukupuolen ja tasa-arvon kysymyksistä ja politiikasta. Rossin kirja soveltuu hyvin myös oppikirjamateriaaliksi, koska se valottaa monipuolisesti ja aineistoesimerkkien avulla, miten heteroseksuaalista sukupuolta ja valkoisuutta rakennetaan. Kirjan antina voidaan pitää erityisesti rikasta ja havainnollistavaa perehdyttämistä normikriittiseen lähestymistapaan, joka lienee vähemmän tuttu heille, jotka eivät ennestään ole lähemmin tutustuneet sukupuolen tutkimukseen ja queer-teoriaan.

Päivi Naumanen

yliopisto-opettaja

Turun yliopisto

\section{LÄHDE}

Keskinen, S., Näre, L. \& Tuori, S. (2015). Valkoisuusnormi, rodullistamisen kritiikki ja sukupuoli. Sukupuolen tutkimus 28(4), 2-5. 